\title{
The NE-SW Trending Fotouni and Fangam Basalt Cones: Evidence of Tectonic Control on Their Emplacement
}

\author{
Nathalie Love Ngongang Tchikankou, Jules Tcheumenak Kouémo, \\ Nicaise Blaise Tchuimegnie Ngongang, Julie Agathe Noudiédié Kamgang, Maurice Kwekam, \\ Pierre Kamgang
}

\section{ABSTRACT}

The Fotouni volcanic rocks outcrop within mylonitic corridor, in the southern domain of the continental part of Cameroon Line (CL). The NE-SW shape display by these volcanic rocks within the mylonitic corridor is an uncommon case along the CL. Field and petrographic data and spaces image analysis were performed in order to understand the NE-SW shape display by these rocks. Geochemical data display two distinct volcanic compositional groups: alkaline lavas and transitional lavas. Alkaline series ranges in composition from basanite, basalt to hawaiite and transitional series range from basalt, trachy-basalt to basaltic trachy-andesite.

Field investigations show that the Fotouni, Fangam, Song and Mbeng basalts outcrops as NE-SW trending prismatic dykes which displaying well differentiated vertical tetragonal, pentagonal and hexagonal prisms within the Fotouni-Kékem shear zone (FFSZ). The overall NE-SW orientation of hills, where these prisms outcrop suggests the tectonic control on the emplacement of these rocks. Indeed, the activation of the FFSZ developed various fracture networks that facilitate magma uplift and the emplacement of the Fomopéa and Bandja plutons during the Pan-African orogeny. These Pan-African activations of the Fotouni fault weaken the crust during the Paleozoic. These weaken zones constitute path way for emplacement of volcanic dykes during the Tertiary within the NE-SW faults, probably facilitated by the general extension at the end of Cretaceous.

Keywords: Fotouni, Cartography, Petrography, Tectonic and magmatism, West Cameroon Highlang, Cameroon Line.
Published Online: October 9,2020

ISSN: $2684-446 \mathrm{X}$

DOI : 10.24018 / ejgeo.2020.1.5.70

\section{N. L. Ngongang Tchikankou}

Department of Earth Sciences, Faculty of Sciences, University of Dschang, Cameroon.

(e-mail: nathalielove34@yahoo.fr)

J. Tcheumenak Kouémo *

Department of Earth Sciences, Faculty of Sciences, University of Douala, Cameroon.

(e-mail: tcheumenak2@gmail.com) N. B. Tchuimegnie Ngongang Department of Earth Sciences, Faculty of Sciences, University of Dschang, Cameroon.

(e-mail: tchuimeniengongang@yahoo.fr) J. A. Noudiédié Kamgang

Department of Earth Sciences, Faculty of Sciences, University of Dschang, Cameroon.

(e-mail: jnoudiedie@gmail.com)

M. Kwékam

Department of Earth Sciences, Faculty of Sciences, University of Dschang, Cameroon.

(e-mail: mkwekam@yahoo.fr)

P. Kamgang

Department of Earth Sciences, Faculty of Sciences, University of Dschang, Cameroon.

(e-mail: pkamgan@yahoo.fr)

*Corresponding Author

\section{INTRODUCTION}

The CVL is an N20E-N30E oceano-continental mega structures consists of plutonic complexes and volcanic cones and extends from the island of Annobon in the Gulf of Guinea to Lake Chad (Fig. 1). The CL magmatic activity covers a large period of time ranging from $70 \mathrm{Ma}$ until the present [1]-[4]. Relationship between tectonic and magmatism in Cameroon is mostly focused on plutonic intrusion [5]-[9] even though the tectonic - magmatism relationship do not concerns only plutonic rocks. Indeed, some authors such as [10], used petrographic and anisotropy of magnetic susceptibility to demonstrate the emplacement of the Foréké-Dschang trachytic dome controlled by a NESW Fault, thus showing that, faults also control the emplacement of volcanic rocks. This paper presents a case in which space images, petrographic and field data were used to demonstrate the influence of fracture on the emplacement of the Fotouni basalts. 


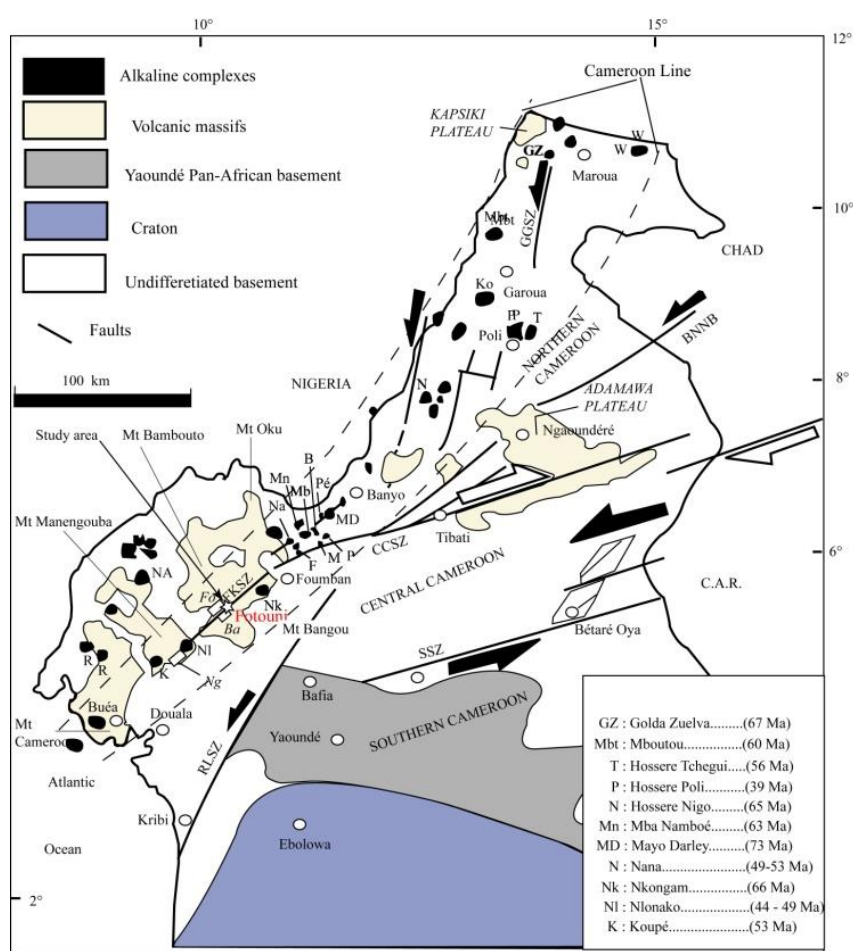

Fig. 1. Location of the study area in the lithostructural map of Cameroon and the Cameroon Volcanic Line, redrawn and adapted from [6]. Lower right: age of the anorogenic complexes cropping out along the Cameroon Line. Alkali ring complexes: NA Nda Ali: K: Koupé; F: Fourougain; M: Mbafé; Mb: Mba Bitou; B: Biridjom; Mn: MbaNamboué; MD; Mayo Darley; Na: Nana; Ni:

HosséréNigo; Nl: Nlonako; Nk: Nkongam; P: Pamsa; Pé: Pandé; P:

HosséréPoli : R: Roumpi; T: HosséréTchegui; Ko: Koukoumi ; Mbt: Mboutou; GZ: Golda Zuelva; W: Waza. Syntectonic plutons: Ba: Bandja; Fo: Fomopéa; $\mathrm{Ng}$ Ngondo; Shear zones (SZ): BNMB = Buffle Noir- Mayo Baleo SZ; CCSZ = Central Cameroon SZ; GGSZ = Godé-Gormaya SZ; RLSZ =

Rocher du Loup SZ; SSZ = Sanaga SZ; FKSZ: Fotouni-Kékem SZ.

\section{GeOlOGICAL SETTING}

Fotouni area is situated in the Fondjomekwet-Fotouni shear zone (Fig. 1; FFSZ) within the western Cameroon highlands. According to previous research works from [11] volcanic rocks from Fotouni are mantle-derived products displaying transitional to alkali series emplaced respectively during the Eocene (47-39 Ma) and Miocene-pliocene (14$3 \mathrm{Ma}$ ). The outcrops of such rock result in the development of several geomorphological units and give rise to the uneven topography. The volcanic rocks from Fotouni crop out in a NE-SW mylonitic corridor displaying porphyritic, fine to very fine grained mylonites from its border to the core [8]. This basement rock is highly sheared and fractured. According to [8], two shear deformational phases are recorded by the FFSZ, and early sinistral and a late dextral. These shear deformation phases were transcurent, developed pull-apart basins which facilitate the emplacement of the Fomopéa and Bandja plutons [8].

Numerous authors show that there is strong relationship between tectonic and magmatism in Cameroon. Numerous of these magmatic bodies are shear zones-related structures along which NNE-SSW to NE-SW elongated syntectonic plutons are emplaced under the control of these shear zones [5]-[9]. Examples are the Fomopéa and Bandja plutons which display as a $\mathrm{N} 30^{\circ} \mathrm{E}-\mathrm{N} 40^{\circ} \mathrm{E}$ sheet-like evidencing their emplacement under the control of a $\mathrm{N} 50^{\circ} \mathrm{E}$ shear zone [7], [8], [12]. In addition, the distribution of volcanic necks in the Biu Plateau appears to be controlled by N-S alignment of Tertiary faults. Based on the fact that Paleocene and Eocene alkali granitein Cameroon (Fig. 1; [13]-[14]) mostly crop out on the CCSZ pre-existing fracture zone, they are considered to be are also faults controlled, according to [15]. Furthermore, part of the CL volcanoes and ring complexes outcrop where the CL crosses fracture zones [13], [16]-[18].

\section{METHODS}

Fresh samples were collected from each rock type during field investigations and used for thin sections processing. During this field works, the geometry and the overall orientation of hills where measure. Theses thin sections were studied under the polarized microscope. Lineament extraction and morphological analysis were performed using Radar satellite data, especially the Shuttle Radar Topography Mission (SRTM) obtained from http: /srtm.csi.cgar.org/-SELECTION/input-Coord.asp, in TIFF format, GSC_WGS_1984 projection was used. SRTM image is an altimetry vector and matrix data available at a resolution of 30 meters. The SRTM image of the study area was used for morphostructural map where lineaments and structures were described, and verifications were done during field investigations.

\section{RESULTS}

\section{A. Geomorphology and rocks distribution}

The space image of the Fig. 2 shows that Fotouni area has the irregular relief dominated by the hills which are separated by V-shape valleys. Three prominent features dominate the landscape: summits, slopes and valleys. The highest point culminates at $1900 \mathrm{~m}$ and the lowest points in valleys are at $1200 \mathrm{~m}$ of altitude. Lithological units observed in the study area are predominantly transitionnal lavas consist of basalt, trachybasalt and basaltic trachy-andesite and alkaline lavas consist by basanite, alkali basalt and hawaiite. All these volcanics are emplaced within a PanAfrican mylonitic basement rock [8]. To the south of Fotouni and Fangam, NE-SW elongated hills are consisted of mylonite (Fig. 2).

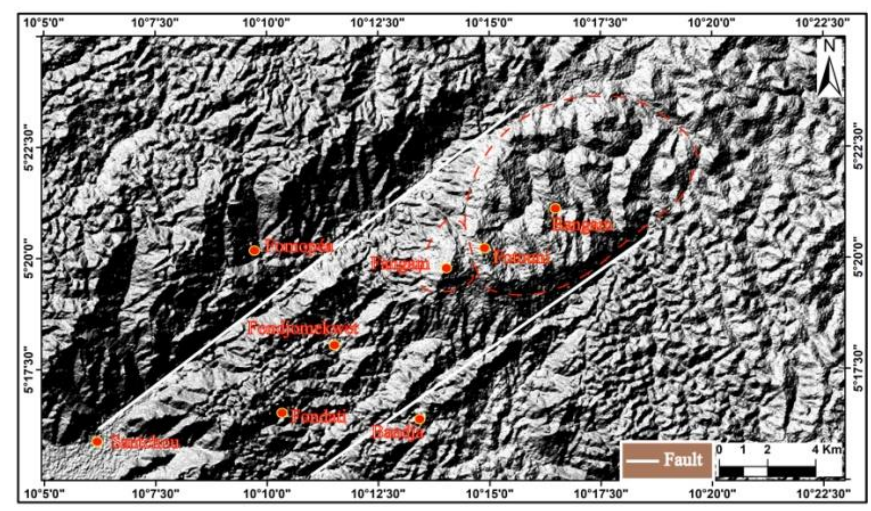

Fig. 2. SRTM image of the study area showing the NE-SW elongated shape of the Fotouni volcanic rocks in the FFSZ.

SRTM image of Fig. 2 indicates that, as the Fondjomekwet-Fotouni mylonitic corridor, volcanic rocks 
display a NE-SW trend. These rocks are located at the topmost part of the Fotouni highlands and these highlands display steep slopes (plateau-like), suggesting a viscous material emplaced within large fractures with very limited flow dynamism.

Data from field studies show that the Fangam, Song and Mbeng basalts outcrop as prismatic dyke trending NE-SW and displaying well differentiated vertical tetragonal, pentagonal and hexagonal prisms (Fig. 3a). In Fotouni, basalts outcrop as undifferentiated dyke (Fig. 3b).

\section{B. Petrography}

\section{B.1. Alkaline rocks}

In the field, alkaline rocks occur to the south of Fotouni and in Fangam as volcanic prism on hills and are melanocratic. They mainly consist of plagioclase, olivine, Fe-Ti oxide and clinopyroxene. Some samples contain dark shiny xenocryst and/or vesicles always coated by such dark secondary infillings. Their textures are variable, depending on the petrographic rock type. Alkaline rocks consist of Basanite, Basalt and Hawaiite.
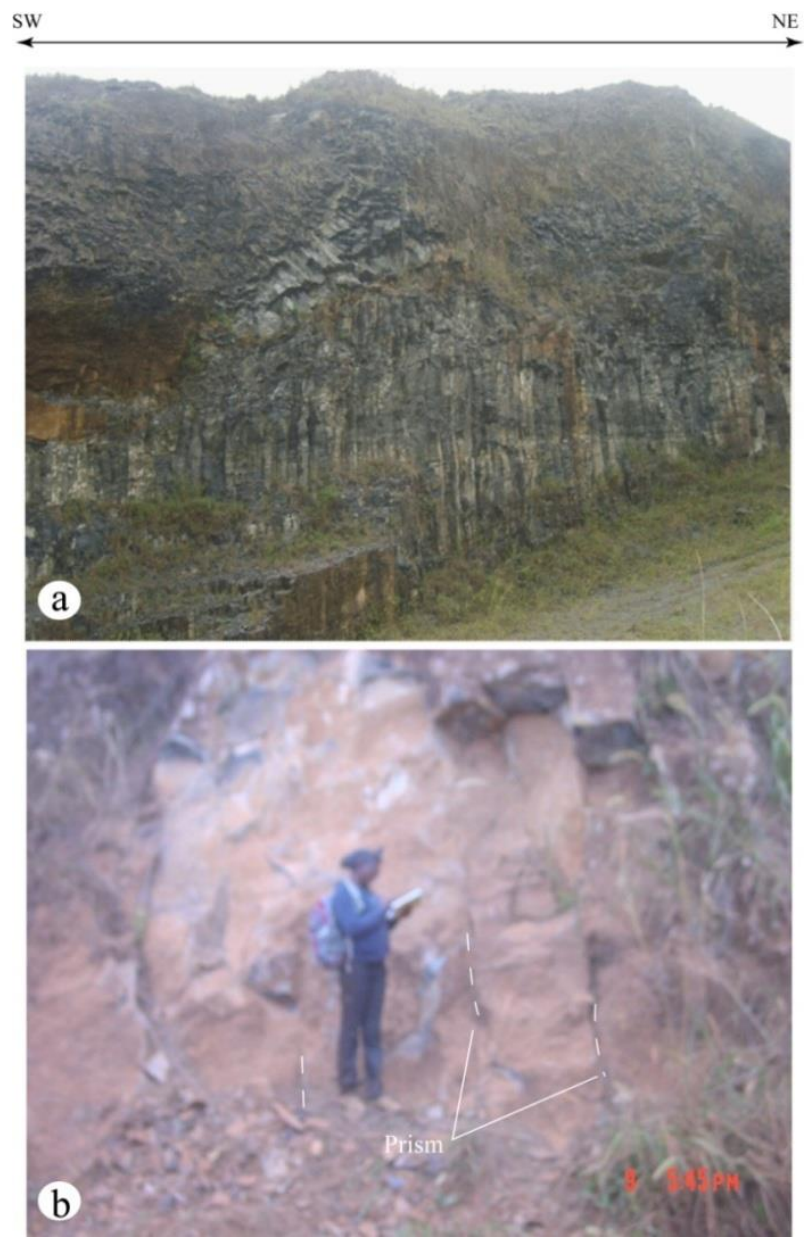

Fig. 3. Volcanic (a) well differentiated and (b) poorly differentiated prisms.

Basanite thin sections display aphiritic texture with some rare plagioclase, olivine and clinopyroxene phenocrysts. In basanite, phenocrysts of olivine $(0.2-0.5 \mathrm{~mm})$ are more or less disseminated between clinopyroxene, Ti-Fe oxide and plagioclase microlites, which are the main component of the groundmass. Mineral proportions in basanites are: $40 \%$ plagioclase feldspar, $25 \%$ oxide, $18 \%$ olivine and $12 \%$ clinopyroxene. They also show fluidal texture characterized by alignment of minerals in the lava flow direction (Fig. 4a).
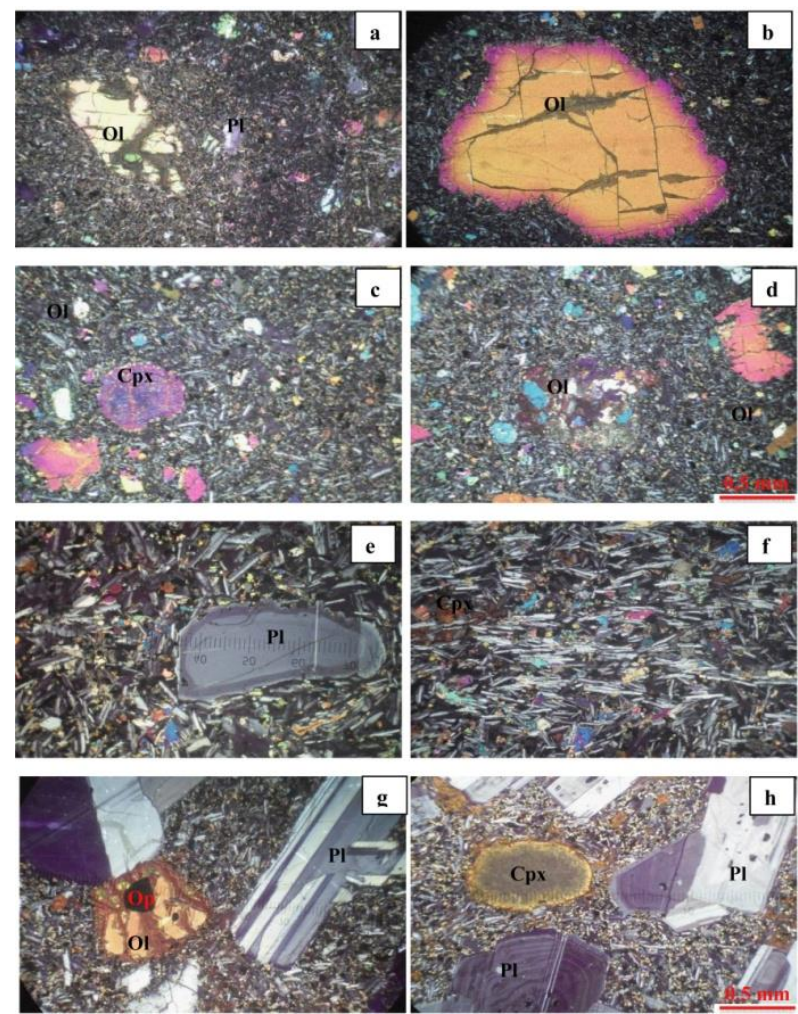

Fig. 4. Thin section photomicrographs of the Fotouni lavas showing some of the significant textures. (a) Polyhedral or granular olivines $(\mathrm{Ol})$ crystals partially pseudomorphosed into secondary minerals; (b) and (c) microlitic fluidal texture with poecilitic microphenocryst of clinopyroxene and fresh xenocryst of plagioclase; (d) porphyric texture with minerals association of phenocryst of plagioclase, olivine and Fe-Tioxyde; zoned plagioclase; fresh olivine crystals.

Basalt are porphyritic with olivine and clinopyroxene (24 and $15 \%)$ as main phenocrysts $(0.5-1.8 \mathrm{~mm})$. Microlites of plagioclase are the more representative of groundmass components. In terms of mass percentage; basalts consist of $30 \%$ of plagioclase feldspar (phenocrysts and microlites), $26 \%$ of oxide, $24 \%$ olivine and $15 \%$ clinopyroxene. The groundmass exhibits a hyalocrystalline texture with olivine, plagioclase, clinopyroxene, oxide and glass sometimes. Olivine phenocrysts are strongly altered to red-brown iddingsite (Fig. 4b). Clinopyroxene phenocrysts exhibit sieve textures or corroded cores, and cleavage. This mineral occurs as subrounded or hexagonal grains in the groundmass.

Hawaiites have typically microlitic porphyritic texture with plagioclase, olivine, clinopyroxene and oxide making up the groundmass (Fig. 4c). However, some hawaiites are highly porphyritic and display olivine megacrysts with size greater than $3 \mathrm{~mm}$ (F21). Porphyritic hawaiites can further be divided into: (1) olivine + clinopyroxene phenocryst hawaiites which display olivine as abundant phenocryst and some rare clinopyroxene phenocrysts but may have groundmass of olivine and clinopyroxene and (2) clinopyroxene phenocrysts hawaiites do not contain plagioclase feldspar phenocrysts in the groundmass. Some of these lavas contain olivine and oxide xenocrysts. 
Hawaiites possess $45 \%$ of plagioclase feldspars (phenocrysts and microlites), (2 to 23\%) olivine respectively for those which are rich in clinopyroxene and poor in olivine (clinopyroxène 20 to $5 \%$ for F14 and F21) and 10\% oxide. The intergranular groundmass is dominated by plagioclase microlites.

\section{B.2. Transitionnal rocks}

In the field, transitional rocks occur to the north of Fotouni and in Bangam, as not differentiated prisms or large blocks on slopes. They are mesocratic to melanocratic, consist of plagioclase, clinopyroxene, Fe-Ti oxide and calcite. Olivine is rare or absent some samples. Some samples contain xenocryst and/or vesicles always coated by such dark secondary infillings. Their textures are variable, depending on the petrographic type.

Basalt is the dominant rock type of the transitional serie. They display porphyritic to aphiritic texture with crystals making up $90 \%$ of the rocks and $10 \%$ of the martix. Porphyritic basalt consists of clinopyroxene (15 to $20 \%$ ), plagioclase (60 to $55 \%$ ) which display very complex zoning with three subdivisions core, intermediate zone and rim, FeTi oxide (20 to $15 \%), 1-3 \%$ of calcite $2-3 \%$ of olivine (Fig. $4 \mathrm{~g}$ and Fig. 4h). Some phenocrysts of plagioclase display triple point junction (Fig. 4h). Clinopyroxene and plagioclase phenocrysts sometimes display reaction rims and are thus interpreted as xenocryst (Fig. 4e and Fig. 4h). Clinopyroxene xenocrystsare slightly altered (F22). Aphyritic basalts display mineral composition similar to porphyritic basalt with some rare clinopyroxene phenocrysts (15 to $20 \%$ ) and plagioclase (60 to $55 \%$ ). The rare plagioclase phenocrysts observed are zoned and display corrosion structure. Clinopyroxene presents poecilitic tendency.

Trachybasalt show fluidal aphiritic texture with rare phenocrysts of plagioclase. Clinopyroxene is ubiquitous, occurring either as a matrix component or as phenocrysts. It can present poecilitic tendency and some crystals are partially replaced by calcite (Fig. 4f). Trachybasalt is composed of $55 \%$ of plagioclase feldspars, $23 \%$ of clinopyroxène, $18 \%$ of oxide, and $2 \%$ of olivine. They also show fluidal texture.

Basaltic trachyandesite displays microlitic aphiritic texture with some rare oxide and clinopyroxene phenocrsyts of disseminated in groundmass dominated by plagioclase microlites. This rock consists of plagioclase microlites $(60$ $\%), 25 \%$ oxides and $10 \%$ clinopyroxene.

Field, petrographic and geochronological data from [11] enable to draw the geological map (Fig. 5). Cross-section from this map shows that, transitional lavas are older than alkaline ones (Fig. 6).

\section{DISCUSSION}

\section{A. Pétrography and crystallization evolution}

Basaltic lavas (alkali and transitional) from Fotouni display olivines and clinopyroxenes, phenocryst and microcryst, plagioclases and opaque mineral. However, the nature and the proportions are different depending on the type of lava.
Plagioclase crystals maintain almost the entire magmatic history of crystallization. This can result from the complex chemical zonation processin addition to the growing often marked by the presence of twins. Indeed, the chemical zonation, the vitreous inclusions in the crystalline structure and the dendritic texture (Fig. 3e and Fig. 3g) display thin sections of rocks indicate a variation in crystal environment during its growth. This variation can be chemical and/or can be pressure-temperature crystallization conditionsdependent. The crystallization of a plagioclase in a cooling magma to constant pressure entails a normal zonation of crystal, with an anorthitic heart and albitic borders [19]. A crystal that is in presence of magma enriched in anorthite or hotter will undergo a resorption in its sides and an inverse zonation [20].

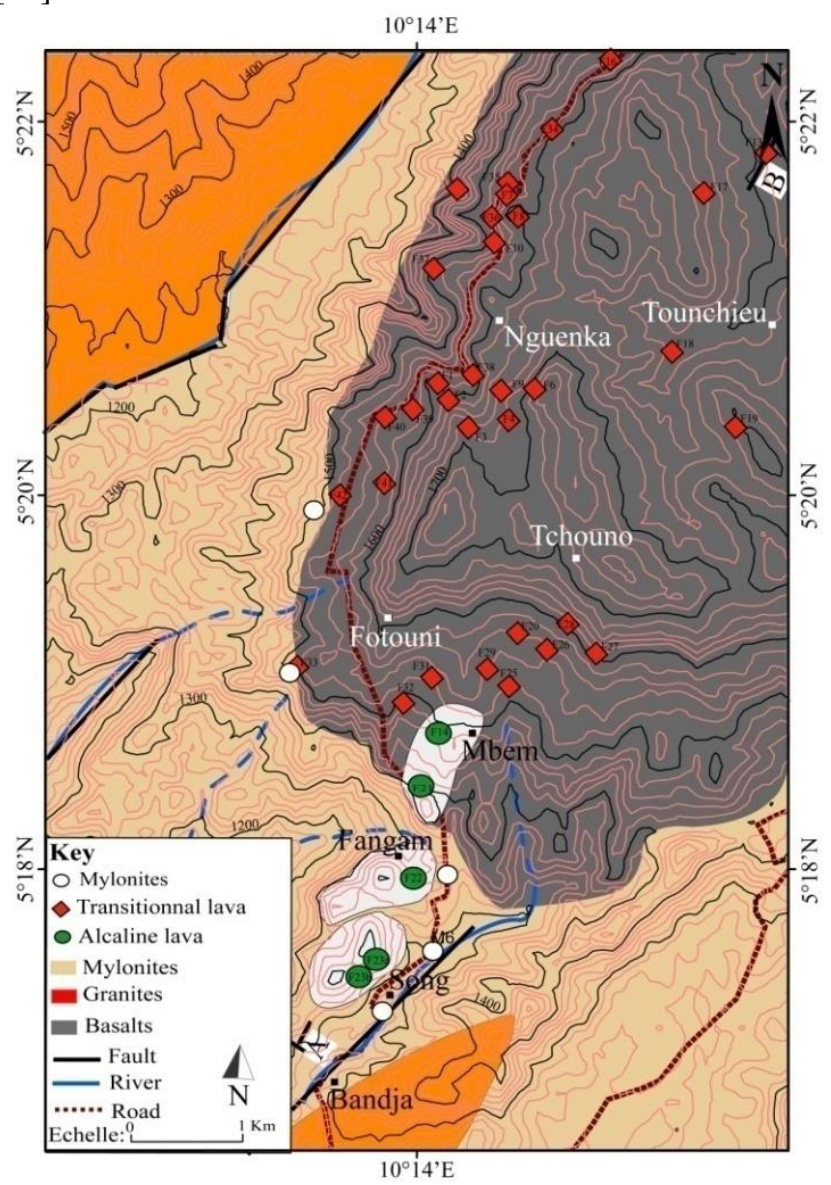

Fig. 5. Geological map of the study area.

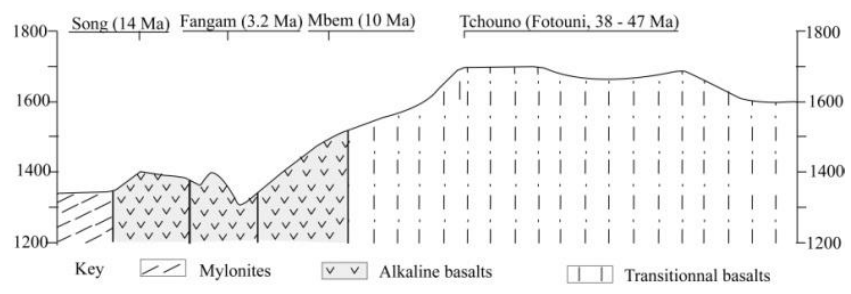

Fig. 6. Cross-section A-B from geological map of Fig. 5.

Plagioclase phenocrysts in the transitional lavas (Fig. $3 \mathrm{~g}$ ) are interpreted as aggregation of several crystals suggesting that, crystals previously had a dendritic texture before becoming euhedral probably due to the acceleration of the crystal growth before the end of the balance period [18]. 
Olivine is abundant and euhedral in alkali lavas and rare in the transitional lavas. Clinopyroxene are xenomorph and abundant in transitional lavas contrary to the alkali lavas in which they are less abundant. Their presence as euhedral phenocrysts suggest that alkali lavas stayed in a deep magmatic chamber.

Opaque mineral inclusions in the clinopyroxene and the inclusions of olivines in the Clinopyroxene within alkaline lavas (Fig. 3d), as well as the inclusions of the opaque minerals in the olivines and the clinopyroxenes within transitional lavas (Fig. 3f) suggest the fractional crystallization phenomenon. The occurrence of olivine and clinopyroxene xenocrysts (Fig. $3 \mathrm{~b}$ and Fig. 3e) suggests that alkaline and transitional lavas underwent a possible crustal contamination.

\section{B. Tectonic control on the prismatic basalt dyke emplacement}

Basalts from Fotouni display vertical prisms thus, corresponding to plateau basalt. Plateau basalts are known to result from the emplacement of large volume of magma within fractures. Indeed, the FFSZ is a faulted corridor which is evidenced in the field by the occurrence of mylonites[7], [8], [12], [20]. According to [8], the activation of the FFSZ developed various fracture networks which facilitate the uplift a mantle-derived magma and the emplacement of the Fomopéa and Bandja plutons to the north and the south of the mylonitic corridor in the one hand, and the emplacement of charnokitic intrusive bodies at Fondanti, within this corridor during the Pan-African orogeny in the other hand. The emplacement magmatic body under tectonic control during the activation of the FFSZ is evidence by the NE-SW trend display by these Pan-African plutons, parallel this NE-SW mylonitic corridor. The emplacement of Fotouni Tertiary volcanic bodies seems to have exploited fractures within the Fondjomekwet-Fotouni mylonitic corridor. Indeed, volcanic bodies in Fotouni and Fangam displays NE-SW trend, parallel to the trending direction of the FFSZ as shown by the SRTM and The occurrence of these rock mostly as vertical prisms in a NESW direction in Fangam and Fotouni (Fig. 2) evidences it emplacement under tectonic control. This emplacement was probably facilitated by extensional phase consecutive to stress release during the late Cretaceous rifting. Indeed, according to [17], [18] the late Cretaceous general stress release lead to a general extension which probably facilitates the uplift of mantle-derived magma and the emplacement of Tertiary anorogenic complexes and volcanic rocks along the Cameroon Line, with no space-time migration display (Fig. 1. This tertiary tectonic control on magmatism is witnessed by the alignment of volcanic cones and ring complexes along the Cameroon Line. According to Landsat image (Fig. 8) the Fotouni basalts are located at the top of the Fotouni plateau and display steep slopes, suggesting the crystallization of these rocks from a very large volume of viscous moderately dynamic magma.

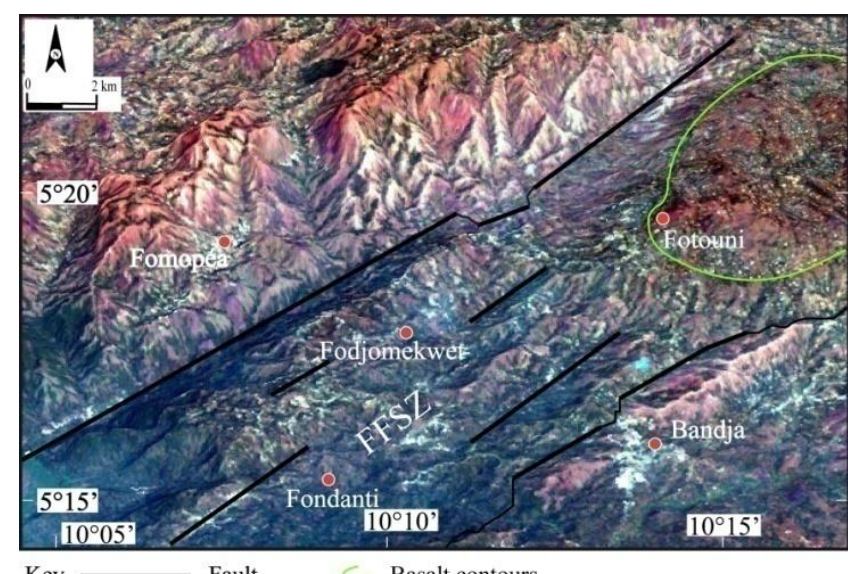

\section{Key - Fault $\subset$ Basalt contours}

Fig. 8. Landsat image of the study are, showing the NE-SW elongated shape of the Fotouni plateau Basalt.

\section{CONCLUSION}

Fotouni basalts crop out in the Western Highland of Cameroon precisely in continental part of Cameroon Volcanic Line (LVC). Alkaline (basanite, basalt to hawaiite) and transitional (basalt, trachy-basalt to basaltic trachyandesite) lavas are the two volcanic groups of these volcanic rocks. Data from field works show that the Fangam, Song and Mbeng basalts are prismatic plateau basalt outcropping as NE-SW trending hills and display well differentiated vertical tetragonal, pentagonal and hexagonal prisms within the Fondjomekwet-Fotounishear zone. The NE-SW orientation and the prismatic shape display by basalts indicate the tectonic control on the emplacement of these rocks due to the late Cretaceous general extension that gave and facilitate the uplift of basaltic magma during the Tertiary.

\section{ACKNOWLEDGEMENT}

This paper is part of the first author Ph.D thesis' data. The authors address their warmest thank to Dr FOZING Eric Martial for his contribution during field works and for his constructive comments which highly improve the quality of the first version of present manuscript. KENFACK Roslin Brice is strongly acknowledged for providing and processing space images.

\section{REFERENCES}

[1] Fitton, J.G., Dunlop, H.M., 1985. The Cameroon Line, West Africa and its bearing on the origin of oceanic and continental alkali basalts. Earth and Planetary Science Letters72, 23-38.

[2] Fitton, J.G., 1987. The Cameroon Line: West Africa: a comparison between oceanic and continental alkaline volcanism, in Fitton, J.G. and Upton, B.G.J., eds., "Alkaline Igneous Rocks". Geological Society of London Special Publication 30, 273-291.

[3] Déruelle, B., Ngounouno, I., Demaiffe, D. (2007). The Cameroon ho line (CHL): A unique example of alkaline intraplate structure in both oceanic and continental. ComptesRendus Geoscience339, 589-600.

[4] Njome, S. M., De Wit J. M. The Cameroon Line: Analysis of an intraplate magmatic province transecting both oceanic and continental lithospheres: Constraints, controversies and models. Earth-Science Reviews, vol. 139: 168-194, 2014.

[5] G, Tagne-Kamga, E, Mercier, M, Rossy, N.E., Nsifa. Synkinematic emplacement of the Pan-African Ngondo igneous complex (Wes Cameroon, Central Africa). Journal of African Earth Science vol. 28, pp. 675-691, 1999.

[6] E., Njonfang, V., Ngako, C., Moreau, P., Affaton, H., Diot. Restraining bends in high temperature shear zones: the "Central 
Cameroon shear zone', Central Africa. Journal of African Earth Sciences, vol. 52, pp 9-20, 2008.

[7] M., Kwékam, J.P., Liégeois, E., Njonfang, P., Affaton, G., Hartmann, F., Tchoua. Nature, origin and significance of the Fomopéa PanAfrican high-K calc-alkaline plutonic complex in the Central African fold belt (Cameroon). Journal of African Earth Sciences, vol. 57, pp. 79-95, 2010.

[8] J., Tcheumenak Kouémo, T., Njanko, M., Kwékam, S., Naba, B.E., Bella Nke, A.F., Yakeu Sandjo, E.M., Fozing, E., Njonfang. Kinematic evolution of the Fondjomekwet-Fotouni shear zone: Implication for emplacement of the Fomopéa and Bandja plutons. Journal of African Earth Sciences, vol. 99, pp. 261-275, 2014.

[9] J., Efon Awoum, E.M., Fozing, M., Kwékam, J., Tcheumenak Kouémo, S.C., Choumele Kana, L. Achu Megnemo. Structural characterization of the Pan-African Ndieki area in the FoumbanBankim Shear Zone (West Cameroon): constraints from field observations and microstructures. Arabian Journal of Geoscience vol. 13, pp. 831, 2020.

[10] B.E., Bella Nké T., Njanko, M., Kwékam, E., Njonfang, S., Naba, J., Tcheumenak Kouemo, M., Gountié Dedzo, P., Rochette, A., Nédélec. Structural study of the Foréké-Dschang trachytic dome (Mount Bambouto, West Cameroon): an anisotropy of magnetic susceptibility (AMS) approach. Journal of African Earth Sciences, 95, 63-76, 2014.

[11] N.L., Ngongang Tchikankou, M., Kwekam, P., Kamgang. G., Chazot, N.B., Tchuimegnie Ngongang, P., Essomba. Caractéristiques des

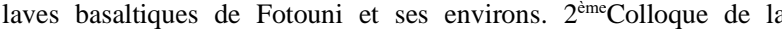
société of Géosciences du Cameroun. Géociences: Levier du Développement Durable. Yaoundé, pp 234, 04-07 Mars 2019.

[12] C., Nguiessi Tchankam, J.P., Nzenti, Nkonguin, E., Nsifa.P., Tempier, F.M., Tchoua. Les granitoides calco-alcalins syncisaillement de Bandja dans la chaîne panafricaine nord-quatoriale au Cameroun. Comptes Rendus de l'Académie des Sciences Paris, vol. 325, pp. 95-101, 1997.

[13] Déruelle, B., Moreau, C., Nkoumbou, C., Kambou, R., Lissom, J., Njonfang, E., Ghogomu, T.R., Nono, A., 1991. The Cameroon Line: a review. In: Kampunzu, A.B., Lubala, R.T. (Eds.), Magmatism in Extensional Structural Settings, The Phanerozoic African Plate. Springer-Verlag, Berlin, pp. 274-327.

[14] Cornachia, M., Dars, R. Un trait structural majeur du continent africain: les linéaments centrafricains du Cameroun au golfe d'Aden. Bulletin de la Société Géologique de France 25, 101-109, 1983.

[15] [15] Moreau, C., Regnoult, J.M., De 'ruelle, B., Robineau, B. A new tectonic model for the Cameroon Line, Central Africa Tectonophysics 139, 317-334, 1987.

[16] Meyers, J.B., Rosendahl, B.R., Harrison, C.G.A., Ding, Z.-D. Deepimaging seismic and gravity results from offshore Cameroon Volcanic Line and speculation of African hot-lines. Tectonophysics 284, 31-63, 1998.

[17] V., Ngako, E., Njonfang, F., Aka Tongwa, P., Affaton, J., Nnange Metuk. The north-south Paleozoic to Quaternary trend of alkaline magmatism from Niger-Nigeria to Cameroon: complex interaction between hotspots and Precambrian faults. Journal of African Earth Sciences vol. 45, pp 241-256, 2006.

[18] Lindsey D.H. Melting relations of plagioclase at high pressures Carneige Institute Washington Year 65, 204, 1966.

[19] J.A., Noudiedie Kamgang, J., Tcheumenak Kouemo, A., Kagou Dongmo, E.M. Fozing, S.C. Choumélé Kana, J., EfonAwoum, G.R., KenfackNguemo. Emplacement and evolution of the Nlonako ring complex in the southern domain of the Cameroon Line. European Journal of Environment and Earth Sciences vol. 1 (4), pp. 1-10, 2020.

[20] L.-C., Kuo, R.J., Kirhpatrick. Pre-eruption history of phyric basalts from DSDP Legs 45 end 46: evidence from morphology and zoning patterns in plagioclase. Contributions to Mineralogy and Petrology, 1982.

[21] Njanko, T., Nédélec, A., Kwékam, M., Siqueira, R., Esteban, L. Emplacement and deformation of the Fomopéa pluton: implication for the Pan-African history of Western Cameroon. Journal of Structural Geology vol. 32, pp. 306-320, 2010

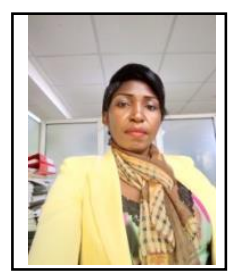

N. L. Ngongang Tchikankou is a Master degrees holder in petrology of volcanic rock at the University of Yaoundé, Cameroon since 2012

She is a secondary school's teacher and also a Ph.D candidate at the University of Dschang.

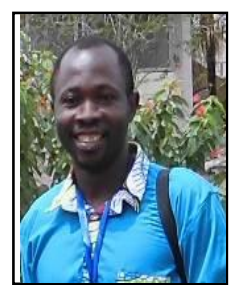

J. Tcheumenak Kouémo is a Ph.D holder in Structural Geology and metamorphic petrology at the University of Dschang, Cameroon since 2018.

Dr Tcheumenak Kouémo is Lecturer at the University of Douala, Cameroon 